\title{
Transfer of Buddhism Across Central Asian Networks (7th to 13th Centuries)
}

\author{
Edited by
}

Carmen Meinert

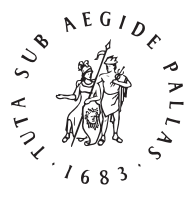

B R I L L 


\section{Contents}

Acknowledgements VII

List of Illustrations, Maps and Tables VIII

General Abbreviations XI

Bibliographical Abbreviations XII

Notes on Contributors XIV

Introduction-Dynamics of Buddhist Transfer in Central Asia $\quad 1$ Carmen Meinert

Changing Political and Religious Contexts in Central Asia on a Micro-Historical Level

1 Changing Relations between Administration, Clergy and Lay People in Eastern Central Asia: A Case Study according to the Dunhuang Manuscripts Referring to the Transition from Tibetan to Local Rule in Dunhuang, 8th-11th Centuries 19

Gertraud Taenzer

\section{Textual Transfer}

2 Tibetan Buddhism in Central Asia: Geopolitics and Group Dynamics 57

Sam van Schaik

3 The Transmission of Sanskrit Manuscripts from India to Tibet: The Case of a Manuscript Collection in the Possession of Atiśa Dīpaṃaraśrījñāna (980-1054) 82

Kazuo Kano

\section{Visual Transfer}

4 The Tibetan Himalayan Style: Considering the Central Asian Connection 121

Linda Lojda, Deborah Klimburg-Salter and Monica Strinu 
5 Origins of the Kashmiri Style in the Western Himalayas: Sculpture of the 7 th-11th Centuries 147

Rob Linrothe

Transfer Agents

6 Buddhism in the West Uyghur Kingdom and Beyond 191 Jens Wilkens

7 Esoteric Buddhism at the Crossroads: Religious Dynamics at Dunhuang, 9th-1oth Centuries 250

Henrik H. Sørensen

Bibliography 285

Index 320 


\title{
Tibetan Buddhism in Central Asia: Geopolitics and Group Dynamics
}

\author{
Sam van Schaik
}

$1 \quad$ Introduction ${ }^{1}$

Tibetan Buddhism has played an important role in Asian politics from the 8th century to the present day. It has provided an ideological underpinning and power status to a variety of Central Asian and Chinese empires, including the Mongol empires of Činggiz Qan's (1162?-1227) heirs and the Manchu rulers of China's Qing Dynasty (1644-1912, 清). While the geopolitical influence of Tibetan Buddhism during this time has waxed and waned over the centuries, it never disappeared. The locus for this influence is in Eastern Central Asia, a crossroads of cultures situated on overland trading routes. The study of this region as a whole is hampered by the variety of cultures it has been home to, and by the dispersal of the archaeological evidence across museums and libraries worldwide.

There have been those who have argued for 'the Centrality of Central Asia' in world history. ${ }^{2}$ Yet even in these revisionist histories the geopolitical influence of Tibetan Buddhism has not been much discussed. In this chapter I will give an overview of the role of Tibetan Buddhism in Central Asia, from its beginnings in the first aspirations of Tibetan emperors to propagate Buddhism across the realm in the 8th century to the development of a mature patronpriest relationship in the Tangut Kingdom in the 13th century. It was during this period that the paradigm for the political function of Tibetan Buddhism developed, one that continued to be invoked through to the 2oth century.

1 Some of the issues raised in this paper have been discussed on my website, earlytibet.com, and I have benefited from the generosity of those who have commented on various posts, including but not limited to Dan Martin, Brandon Dotson and Andrew West. My thanks to Imre Galambos and Susan Whitfield for their comments on the text, and to David Rutherford for discussing current sociological literature about intergroup and intragroup relations.

2 See Beckwith, Christopher, Empires of the Silk Road (Princeton: Princeton University Press, 2009), xix-xxv; Frank, Andre Gunder, The Centrality of Central Asia (Amsterdam: vu University Press, 1992). 
In order to understand the development of Tibetan Buddhism's influence we can use historical texts, where they exist. But here I want to emphasise that archaeological finds can also be very informative. In fact, it is in these archaeological finds-manuscripts, paintings and other artefacts-that the continuity of Tibetan Buddhism's role in Central Asia becomes most evident. Reconstructing the social role of these objects can help us to understand the impact of large-scale political events on local practices. And local practices can indeed help us to understand the causes and conditions underlying large-scale events. This is an argument for the complementarity of micro and macro histories, an argument that has been most developed in the field of sociology. For example, Randall Collins has written that "macrostructure consists of nothing more than large numbers of micro-encounters, repeated (or sometimes changing) over time and across space."3 Donald Ellis argues that "the microworld of everyday communication is the site of meaning that both produces social structure and is produced by it." ${ }^{4}$ And Bruno Latour has repeatedly shown that larger structures are indeed only possible because of the extension of networks through the repeated practice of small-scale activities. ${ }^{5}$

In history, it is in the archaeology of texts and artefacts that these local practices — or micro-encounters - can be examined. ${ }^{6}$ This essay is an experimental attempt to combine the recovery of local practice from archaeology with a longue durée approach to large-scale trends in the hope that it will further our

3 Collins, Randall, "Interaction Property Chains, Power, and Property: The Micro-Macro Connection as an Empirically Based Theoretical Problem," in The Micro-Macro Link, ed. J. C. Alexander et al. (Berkeley: University of California Press, 1987), 195.

4 Ellis, Donald, "Research on Social Interaction and the Micro-Macro Issue," Research on Language and Social Interaction 32 (1999): 33 .

5 See especially Latour, Bruno, Reassembling the Social: An Introduction to Actor-Network Theory (Oxford: Oxford University Press, 2005), 37. Latour's work owes a debt to previous sociological work on the function of practices in maintaining and changing social structures; see especially Bourdieu, Pierre, Outline of a Theory of Practice (Cambridge: Cambridge University Press, 1977); Giddens, Anthony, The Constitution of Society (Cambridge: Polity Press, 1986).

6 In the academic discipline of history itself, the enthusiasm for the genre of micro-history seems to have waned, perhaps due to the unrealistic expectations of the original phase of enthusiasm. Another factor in the faltering of the micro-history project may be the academic roles of its proponents within History departments, primarily in dialogue with other historians, rather than archaeologists and sociologists. See the ambivalent discussion of microhistory in by Ginzburg, Carlo, "Microhistory: Two or Three Things That I Know about It," trans. John Tedeschi and Anne C. Tedeschi, Critical Inquiry 20.1 (1993): 10-35, and the ultimately negative assessment by Lamoreaux, Naomi, "Rethinking Microhistory: A Comment," Journal of the Early Republic 26.4 (2006): 555-561. 
understanding of how Tibetan Buddhism (in its Tantric or Vajrayāna forms in particular) became a dynamic force in Eastern Central Asia and beyond.

The Tibetan Empire was first established during the reign of the Emperor (Tib. btsan po) Tri Songtsen (Tib. Khri Srong btsan, r. c. 605-649). The extent of the empire declined after the end of his reign, but expanded again after the Tang Dynasty (618-907, 唐) was weakened by the An Lushan (安祿山) rebellion in the middle of the 8th century, when the Emperor Tri Song Detsen (Tib. Khri Srong lde btsan, r. 742-c. 80o) took control of the whole of Eastern Central Asia. From this point until the middle of the 9th century, the Tibetan Empire was not only one of the major powers of Asia, but controlled the key trade routes that ran through the heart of the continent. In this position, it became both wealthy and culturally influential.

The adoption of Buddhism as a state religion by the emperors of Tibet is traditionally said to have been an act of piety, born out of religious conviction. Modern historians have tended to see it as a political act, motivated by the significant presence of Buddhism among Tibet's powerful neighbours. Matthew Kapstein has argued that Buddhism presented a framework for universal legislation, an ideology that could be extended across an empire embracing a wide range of cultures. ${ }^{7}$ Substantial imperial resources were turned to the task of making Tibet a Buddhist country, with the building of monasteries and the translation en masse of Buddhist texts from India and to a lesser extent from China.

While some have suggested that the Buddhism of the Tibetan Empire was an elite and primarily a court-based religion, there is evidence that the later emperors were keen to spread the Buddha's teachings across the realm. The adoption of Buddhism as a state religion occurred during the latter part of the reign of the emperor Tri Song Detsen. His second edict, probably published in 779, records the way in which Buddhism was made the state religion of Tibet. Looking very much like the official minutes of a meeting, it describes various discussions during which the court deliberated on how to establish Buddhism in Tibet, beginning with Trisong Detsen's own account of how he was converted to Buddhism:

7 Kapstein, Matthew, The Tibetans (Oxford: Blackwell, 2006), 61-62. 
Then with the help of teachers of virtue I listened to the dharma and the texts were brought before my eyes. Then I deliberated upon how the Buddhist religion should be practised and spread. ${ }^{8}$

Note here the stress laid by the emperor on the spread or propagation (Tib. spel) of Buddhism. This concern was addressed in a later meeting convened by Tri Song Detsen, this time with lords from all over the Tibetan Empire, including the Azha (Tib. 'A zha), the former rulers of Eastern Central Asia, known by the Chinese as Tuyuhun (吐谷渾). According to the edict, at this meeting everyone agreed to an empire-wide project establishing Buddhism, with a caveat that the traditional ways of the ancestors should be followed as well.

The minor princes under our dominion, such as the Azha ruler, and the outer and inner ministers were consulted and a council was held. Together they considered in brief these things, first that trust should be put in the word of the Buddha; secondly that the example of the ancestors should be followed; and thirdly that help should be given by the power of the teachers of virtue $[\ldots]$. Further to that, a council was held about how the right path should not be changed, and how it could be increased. Thus an excellent summary of the dharma was made. ${ }^{9}$

This summary of the dharma probably relates to what is written earlier in the edict, where the emperor explains the basics of Buddhism: the fact of impermanence, the inevitability of cause and effect and the need to practise the ten kinds of virtuous action in order to obtain a good rebirth. A few decades later the Emperor Tri De Songtsen (Khri lDe srong btsan, r. c. 802-815) published an edict that was carved on a stone pillar at Karchung (Tib. sKar cung) about the appointment of senior Buddhist teachers in Tibet. It says:

8 My translation; Tibetan text from Richardson, Hugh, High Peaks, Pure Earth: Collected Writings on Tibetan History and Culture (London: Serindia Publications, 1998), 97 (110b): de nas dge ba'i bshes gnyen gyis bstangs te chos kyang gsan / yi ge yang spyan sngar brims nas / sangs rgyas kyi chos spel zhing mdzad par bsgroms so //

9 My translation; Tibetan text from Richardson, High Peaks, Pure Earth, 98 (110b): 'bangs su mnga' ba rgyal ba rgyal phran 'a zha rje la bstsogs pa dang phyi nang gi blon po rnams la bka's rmas / bka' gros su mdzad nas / gcig tu na sangs rgyas bcom ldan 'das kyi bka' lung la bsten / gnyis su na yab mes kyi dpe lugs la 'tshal / gsum du na dge ba'i shes gnyen gyi mthus bstangs pa dang yang sbyar nas mdor brtags na / [...] de lam legs par ni ji ltar myi 'gyur ched ni ji ltar che zhe na / chos kyi mdo ni legs su bgyi bas / 
But from the time when the emperor and his descendants are young until the time when they become rulers of the kingdom and thereafter, teachers of virtue shall be appointed from among the monks. By teaching religion as much as can be absorbed into the mind, the gate of liberation for the whole of Tibet, through the learning and practice of the dharma, shall not be closed.

Note here the apparently inclusive statement that the whole of Tibet will have access to the gate of liberation. This egalitarian sentiment is made even more clearly further down the pillar:

And when for the Tibetan subjects from the nobles downwards, the gate leading to liberation is never obstructed and the faithful have been led towards liberation, from those among them who are capable there shall always be appointed abbots to carry on the teachings of the Buddha. ${ }^{10}$

It seems clear that the phrase from the nobles downwards must include every Tibetan subject, however lowly. Thus at this point, while Tibetan Buddhism may still have been largely a religion of the elite, there was a clearly stated aspiration that everyone irrespective of social class should practice it.

If we look at the contemporary manuscript evidence from the Dunhuang cave library, there are clues as to how this wide-ranging conversion was to be carried out. During the reign of Tri Tsug Detsen (Tib. Khri gTsug lde bstan, r. 815-841) vast quantities of copies of Buddhist sūtras were commissioned (particularly the large Prajñāpāramitāsūtras and the Aparimitāyussūtra). While such projects were perhaps less an exercise in conversion than in the generation of stores of religious merit, it did require the training of large numbers of scribes, most of them Chinese, in the Tibetan language. At this time, the Tibetan court seems to have extended the project of propagating Buddhism across different languages, not merely in Tibetan. Among the Dunhuang

10 My translation; Tibetan text from Richardson, Hugh, A Corpus of Early Tibetan Inscriptions (London: Royal Asiatic Society, 1985): 78-79 (1l.33-42). / / btsan po dbon sras / / sku chu ngur bzhugs payan cad / / chab srId kyi mnga'bdag mdzad pa man chad kyang // dge slong las / dge ba'I bshes nyen bskos ste / chos thugs su cI chud chud du bslab cing / / bod yongs kyIs kyang chos slob cing spyad pa'I sgo myi gcad / nam du yang bod ya rabs man cad/bod 'bangs las thar par gzud pa'I sgo myi bgag par / dad pa'I rnams las thar par btsud de / / de'i nang nas nus pa las / / bcom ldan 'das kyI ring lugs rtag du bsko zhIng / / bcom ldan 'das kyI ring lugs byed pa'I rnams chos 'khor nas bya'o cog gI bka' la yang btags ste // 
manuscripts there is a scroll (Or. 8210/S. 3966) with a short Buddhist text in Chinese. Its colophon says:

In the sixth month of the water tiger year, a letter was issued with the seal of the Tibetan king (Chin. zanpu 讃菩) to be circulated throughout the prefectures of Greater Tibet with copies of this Sütra of the Ten Virtues for widespread recitation. On the 16th day of the following eighth month this note was written after the completion of the copying. ${ }^{11}$

The colophon refers to a previous edict ordering the copying of the Sütra of Ten Kinds of Virtuous Behaviour across the whole of Great Tibet (that is, the full extent of the Tibetan Empire). ${ }^{12}$ Similarly, a Chinese scroll containing the Sütra of Impermanence (P. tib. 735) has a Tibetan colophon stating that it was copied in the reign of Tri Tsug Detsen as a religious offering of the emperor. ${ }^{13}$ These two sütras address two of the main themes of the summary of Buddhism that Tri Song Detsen composed after his imperial council: impermanence and the practice of virtue.

It does not seem unreasonable to link these manuscripts found at one of the further corners of the Tibetan Empire with the aims expressed by Tri Song Detsen and his successors. The manuscripts suggest that one way in which this aspiration was put into practice was in the copying of various brief summaries of the Buddhist doctrine all over Tibet, which would then have been taught orally to the non-literate through recitation, presumably, though literacy seems to have been quite widespread by the end of the empire. These clues, sparse as they are, suggest the means by which the Tibetan imperium propagated Buddhism through to the dissolution of the empire in the middle of the gth century. In this, the imperium seems to have been very successful, planting the seeds for the further growth of Tibetan Buddhism after the empire itself ceased to exist.

11 Or. 8210/S. 3966 colophon: 王寅六月大蕃國有讃菩印信, 并此十善經本, 傳流 諸州，流行讀誦，後八月十六日寫畢記.

Translation made with the help of Kazushi Iwao.

12 The matter is complicated by the fact that the Chinese text on the scroll S. 3966 is not called The Sütra of the Ten Virtues. It is The Summary of the Essential Points of the Mahāyāna Sūtras [Dasheng jing zuanyao yi 大乘經纂要義]. As the latter text does have a section on the ten virtues, it may have been copied as the best match, given that there is no extant Sütra of the Ten Virtues in Chinese.

13 The Tibetan colophon of P. tib. 735://dar ma 'dI ni myi rtag pa'I mdo shes bgyI'o////bod gyi lha btsan po khri gtsug lde brtsan kyI sku rIngs la//lha sras kyI sku yon du sngos pa//sha cu'I gnas brtan dang/'dul dang//khri [...] 
The reasons for the decline and fall of the Tibetan Empire are complex and still not well understood. Traditional Tibetan accounts blaming an anti-Buddhist purge by the Emperor Lang Darma (Tib. gLang dar ma, r. 841-842) do little to explain it, and are belied by the evidence of Buddhist patronage by his queen and sons. There does seem to have been an irreconcilable split in the ruling house after Darma's death, breaking the contract by which only one heir could be recognised as the emperor. Shortly afterwards, the further corners of the empire were claimed by others. In 848 Dunhuang was conquered by a local Chinese army and thereafter ruled by Chinese families. ${ }^{14}$ Other strongholds in Central Asia fell soon afterwards.

The era following the break up of the empire is known by Tibetan historians as the age of fragmentation (Tib. sil bu'i dus). Traditional Buddhist historians saw the era mainly in terms of the collapse of monastic Buddhism and its eventual re-establishment in Central Tibet. In these accounts, the monastic ordination lineage was preserved in Northeast Amdo, in the modern Qinghai and Gansu provinces. Although reliable historical information about this time is difficult to come by thanks to the decline of both Tibetan and Chinese power, it is clear that this region, which had been taken by the Tibetan Empire from the Azha in the $7_{\text {th }}$ century, remained a stronghold of Tibetan culture after the fall of the empire.

An important source is the Dunhuang manuscript IOL Tib J 754, which contains a series of letters of passage for a Chinese monk passing through the Tibetan confederations of Tsongkha (Tib. Tsong kha) and Liangzhou (凉州) on his way to India in the late 96os. The letters are evidence of thriving Tibetan monastic communities during this period. The annals of the minor Chinese Kingdoms that bordered on this region record regular visits by Tibetan envoys, and occasional military incursions by Tibetan armies. It is not likely that these Tibetans came from Central Tibet. More likely they were from the local petty kingdoms of Tibetanised Azha and other ethnic groups. Here I refer to them as Tibetan in the wider sense, referring to all ethnic groups who adopted Tibetan language and culture during the imperial period. ${ }^{15}$

14 For a micro-analysis of religion and politics in Dunhuang during the transition from Tibetan to local rule see the article by Gertraud Taenzer in this volume.

15 On the petty Tibetan Kingdoms of Northeast Amdo/Eastern Central Asia, see Iwasaki, Tsutomu, "The Tibetan Tribes of Ho-hsi and Buddhism during the Northern Sung Period," Acta Asiatica 64 (1993): 17-37; van Schaik, Sam, and Imre Galambos, Manuscripts 
We have a slightly better picture of the Tibetans after the advent of the Song Dynasty (960-1279, 宋) in China. The History of the Song Dynasty (Chin. Songshi 宋史) mentions two successive rulers of Liangzhou in the tenth century, both of whom assumed the Tibetan imperial title Tsenpo (Tib. bstan po). ${ }^{16}$ Then in the eleventh century the Tibetan city of Tsongkha came to the notice of the Song when a minor scion of the Tibetan royal family was brought there in order to establish a new ruling dynasty in the area. He and his descendants were known as Juesiluo (唃廝囉), probably a Chinese transliteration of a Tibetan word gyalse (Tib. rgyal sras) that can mean both prince and bodhisattva. Ruth Dunnell has pointed out that, since this coup was orchestrated by the local Tibetans, it is likely that the Tibetans were already ruling the Tsongkha region earlier in the 1oth century, and this is confirmed by the letters in IOL Tib J 754, which contains direct evidence of the activities of local Tibetan rulers in this very area. ${ }^{17}$

The Song Dynasty grew in influence over the 1oth century, but never extended across Eastern Central Asia as the early Tang Dynasty had done. Instead Song rulers courted these local Tibetan rulers to keep its borders safe. In a new and vitally important development, an increasing number of these rulers were also monks, as the History of the Song Dynasty reports that they were awarded the purple robe for their efforts - a traditional symbol of imperial recognition of religious leaders. The letters of passage in IOL Tib J 754 also suggest that the distinctions between political and religious roles had already been blurred by the middle of the tenth century. ${ }^{18}$

These two aspects of religio-political life in this region in the 1oth and 11th centuries - the merging of religious and political roles and the increasingly successful moves by some Tibetan Buddhists to find support from powerful patrons from other cultural backgrounds - are a pattern that became increasingly important to the geopolitics of Central Asia and beyond in the following

and Travellers: The Sino-Tibetan Documents of a Tenth-Century Buddhist Pilgrim (Berlin: de Gruyter, 2012), 63-67.

16 Immediately after this period, Liangzhou was ruled by Panluozhi (潘羅支, which perhaps stands for the Tibetan name 'Phan bla rje), who came to power in 1001. It is testament to the wealth of Liangzhou at this time that he was able to send 5,00o horses to the Song capital as a tribute. See Iwasaki, "The Tibetan Tribes," 18.

17 See Dunnell, Ruth, The Great State of White and High: Buddhism and State Formation in Eleventh-Century Xia (Honolulu: University of Hawai'i Press, 1996): 173-174; van Schaik and Galambos, Manuscripts and Travellers, 147-176.

18 On the bestowing of purple robes on Tibetan monk-rulers see Iwasaki, "The Tibetan Tribes," 22-24. On the relevant letters in IOL Tib J 754 see van Schaik and Galambos, Manuscripts and Travellers, $167-169$. 
centuries. Before we move on to this later period, I want to suggest some reasons how Tibetan Buddhism (and Tibetan Tantric Buddhism in particular) made this possible.

\section{$4 \quad$ Tantric Practice in the Tenth Century}

The abovementioned sources clearly show a major shift during the century after the fall of the Tibetan Empire from a Centralised and state-sponsored Buddhism to a dispersed model in which Buddhist practice and ideology was adopted in various ways by local political rulers. The manuscripts and other artefacts from the Dunhuang cave can shed light on the kind of Buddhism that was being practised at this time by these monks and rulers. They show in particular the rise in popularity of Tantric forms of Buddhism, including many aspects of what we now regard as the specifically Tibetan forms of Buddhism, such as the significant presence of the deity Avalokiteśvara (Tib. sPyan ras gzigs dbang po) and the master Padmasambhava (Tib. Padma 'byung gnas). The manuscripts also show the development of some of the organisational rubrics that came to characterise the Nyingma school of Tibetan Buddhism, including the nine vehicles of Buddhist teachings and the twenty-eight Tantric vows, or samaya. ${ }^{19}$

But it was the practices of the Tantric genre of Mahāyoga that seem to have been most popular and influential during this period. Mahāyoga was essentially a Tibetan adaptation of a genre of Tantric texts and practices derived

19 On the early cult of Avalokiteśvara see van Schaik, Sam, "The Tibetan Avalokiteśvara Cult in the Tenth Century: Evidence from the Dunhuang Manuscripts," in Tibetan Buddhist Literature and Praxis (Proceedings of the Tenth Seminar of the IATS, 2003, Volume 4), ed. Ronald M. Davidson and Christian Wedemeyer (Leiden: Brill, 2006), 55-72. On Padmasambhava in the Dunhuang manuscripts, see Dalton, Jacob, "The Early Development of the Padmasambhava Legend in Tibet: A Study of IOL Tib J 644 and Pelliot tibétain 307," Journal of the American Oriental Society 124.4 (2004): 759-72. On the nine vehicles in the Dunhuang manuscripts see Karmay, Samten, The Great Perfection (rDzogs chen): A Philosophical and Meditative Teaching of Tibetan Buddhism (Leiden: Brill, 1988), 172-73; Dalton, Jacob, "A Crisis of Doxography: How Tibetans Organized Tantra during the 8th-12th Centuries," Journal of the International Association of Buddhist Studies 28.1 (2005): 132-51.

On the twenty-eight vows or samaya (Tib. dam tshig) of Mahāyoga, see van Schaik, Sam, "The Limits of Transgression: The Samaya Vows of Mahāyoga," in Esoteric Buddhism at Dunhuang: Rites and Teachings for this Life and Beyond, ed. Matthew T. Kapstein and Sam van Schaik (Leiden: Brill, 2010), 63-72. 
from India. ${ }^{20}$ The Tantric literary background to Tibetan Mahāyoga practices includes the Guhyasamāja and Guhyagarbha tantras, and the related sädhana practice texts, that is, ritual manuals. These texts draw on the general framework of previous Tantric practice, but are characterised by a more explicit incorporation of sexual and violent imagery. Whether Mahāyoga practice entailed acts of sex and violence, or rather imagined or simulated versions, is still debated..$^{21}$ In any case, both of these aspects of Mahāyoga, known as union and liberation (Tib. sbyor sgrol) are techniques of power, the sexual practices resulting in power over the internal realm of the body, and the violent practices resulting in power over the external realm.

There are several hundred manuscripts containing Tantric texts in the collection from the Dunhuang cave. These have been catalogued and individual texts have been discussed at length; however, looking at some of these manuscripts as a whole, rather than extracting particular texts for study, may reveal more about actual practices. Many of the Tantric manuscripts contain multiple texts, and these are often clearly arranged in the order they would be used in a ritual. Some of the texts are narratives or sequences of questions and answers, which would be used in sermons or lectures as part of the ritual, implying the presence of a master and audience of disciples. Some manuscripts contain dedications to the sponsors of the ritual. Many of these ritual sequences conclude with the activities of offering and confession, conventional to Buddhist group practices. ${ }^{22}$

Other artefacts from the cave are items that would have been used in these Tantric rituals. We have, for example, a ceremonial five-pointed crown illustrated with the figures of the five buddhas of the mandala, which would have been worn by the master and initiates in a Tantric empowerment ritual. We also have a small image of the deity Vajrasattva, the Central figure of peaceful

20 On the Tibetan interpretations of Mahāyoga, see van Schaik, Sam, "A Definition of Mahāyoga: Sources from the Dunhuang Manuscripts," Tantric Studies 1 (2008): 45-78.

As far as we know the term was not used to refer to a genre of literature and practice in the Indian context (personal communication, Harunaga Isaacson).

21 On the violent imagery in Mahāyoga tantra, and Tibetan responses to it, see Dalton, Jacob, The Taming of the Demons: Violence and Liberation in Tibetan Buddhism (New Haven: Yale University Press, 2011).

22 An interesting example discussed in Dalton, The Taming of the Demons, 77-94, is a manuscript in concertina format now kept in both the Pelliot collection in Paris and the Stein collection in London: the first part of the manuscript is in Paris (P. tib. 36), the middle in London (IOL Tib J 419) and the end once again in Paris (P. tib. 42). For other examples of the ritual sequence of Mahāyoga practices, see van Schaik, "A Definition of Mahāyoga," $74^{-} 75$. 
Mahāyoga practices. This appears to be a tsakli, a card used in the context of an empowerment. The ritual use of such crowns and illustrated cards continues in the Tibetan Buddhist tradition to the present day. There are also many examples of diagrammatic sketches of mandalas that seem to have been used for ritual purposes, either as models for visualisation or for the layout of a physical mandala. ${ }^{23}$

The picture that emerges from manuscripts and artefacts such as these is of groups under the guidance of a Tantric master, supported by one or more patrons. In a ritual performance, the master would demonstrate his or her authority through explicating the ritual and its narrative context. The patron, who may not necessarily be present, makes the practice possible through sponsorship; and this patron is also the main beneficiary of the religious merit generated by the ritual. Finally the disciples perform recitation and visualisation based on the guidance of the Tantric master. Thus these sequences of texts bind their practitioners into Buddhist communities (whether lay or monastic) through the communal activities of offering, prayer recitation, and confession.

We have a few clues as to the identity of the people who inhabited these roles, in the names of patrons inscribed within some of the practices, and the names of the scribes who copied out the texts. These show the highly multicultural nature of those engaged in Tibetan Buddhist practice. Though most of the manuscripts are unsigned, of those that are, several bear the names of Chinese scribes, including a copy of a popular treatise on Mahāyoga signed by a Meng Huaiyu (孟懷玉) who served in the official post of a Vice Commissioner (Chin. fushi 副使), the third highest ranking official in the local government. ${ }^{24}$ Other Tantric manuscripts were written by Khotanese and Uyghur scribes. Thus it is clear that Tibetan Buddhism, and Tibetan Tantric Buddhism in particular, cut across cultural/linguistic boundaries. ${ }^{25}$

23 The five-buddha crown is P. 4518(7), from the Bibliothèque nationale de France and the Vajrasattva implement is IOL Tib J 1364. An example of a mandala diagram is the British Museum 1919,0101,0.173 from the British Museum. All can be seen on the website of the International Dunhuang Project (idp.bl.uk, accessed 4 February 2015). On the ritual usage of items such as these, see Fraser, Sarah, "Formulas of Creativity: Artist's Sketches and Techniques of Copying at Dunhuang," Artibus Asiae 59.3-4 (2000): 204, 221; Wang, Michelle, "Changing Conceptions of 'Maṇalala' in Tang China: Ritual and the Role of Images," Material Religion 9.2 (2013): 198-209.

24 See Hucker, Charles, A Dictionary of Official Titles in Imperial China (Stanford: Stanford University Press, 1985), 216 where fush $i$ is translated 'Vice Commissioner'.

25 On the manuscript written by Meng Huaiyu, see van Schaik, Sam, "The Sweet Saint and the Four Yogas: A 'Lost' Mahāyoga Treatise from Dunhuang," Journal of the International Association of Tibetan Studies 4 (2008): 23-26. For other manuscripts showing evidence of 
This was made possible by the widespread training in the Tibetan language and script that was enforced during the Tibetan Empire, which resulted in a generalised use of the language across different cultural/linguistic groups in official communication and religious literature. After the fall of the empire, the Tibetan language persisted as the lingua franca of Eastern Central Asia. ${ }^{26}$ It was, for example, at one point the language chosen for communication between the Chinese ruler of Dunhuang and the king of Khotan. Thus at the point when Mahāyoga practices transmitted through the medium of Tibetan were becoming increasingly popular, there was a general knowledge of Tibetan as a first or second language across a range of ethno-linguistic groups.

5

\section{Tantric Group Dynamics}

The Tantric empowerment rituals of Mahāyoga are based on previous Buddhist induction ceremonies for monastic and lay practitioners - ceremonies that committed one to certain kinds of everyday practice. In a wider context, the practice of group initiation followed by daily personal observance is one of the most commonly seen ritual structures for religious and other social groups. Since Durkheim, sociologists and anthropologists have examined the social role of practices such as these. The contemporary study of the formation and functioning of such groups under the heading of group dynamics may have something to contribute to our understanding of the role of Tibetan Tantric Buddhism in Central Asia. ${ }^{27}$

the use of Tibetan among non-Tibetans, see van Schaik, and Galambos, Manuscripts and Travellers, 29-34. And on the multicultural nature of Dunhuang society, see Takata, Tokio, "Multilingualism at Tun-Huang," Acta Orientalia 78 (2000).

26 This has been discussed by Takeuchi, Tsuguhito, "Sociolinguistic Implications of the use of Tibetan in East Turkestan from the End of Tibetan Domination through the Tangut Period (9th-12th c.)," in Turfan Revisited - The First Century of Research into the Arts and Cultures of the Silk Road, ed. Desmond Durkin Meisterernst et al. (Berlin: Dietrich Reimer Verlag, 2004), 341-348; see also Takeuchi, Tsuguhito, "Old Tibetan Buddhist Texts from the Post-Tibetan Imperial Period (mid-9 C. to late 10 C.)," in Old Tibetan Studies: Proceedings of the Tenth Seminar of the IATS, 2003, ed. Cristina Scherrer-Schaub (Leiden: Brill, 2012), 205-214. [Revised version distributed by the author.]

27 A classic work in the field of group dynamics is Brown, Rupert, Group Processes: Dynamics Within and Between Groups (Oxford: Blackwell Publishing, 200o).

For a survey of the issues and literature, see Stangor, Charles, Social Groups in Action and Interaction (New York: Psychology Press, 2004). 
One of the features of Tantric Buddhism in Tibet and Tibetan-speaking Central Asia is that the exponents of the most recent developments in Tantric practice were usually the most successful in gaining followers. In the 1oth century this was the Mahāyoga of the Guhyasamāja and Guhyagarbha tantras, though this would soon be supplanted by a new wave of translations. Thus it seems that those who offered empowerments into these 'new' systems gained a greater following and patronage, which would have encouraged others to adopt these systems as well. The ritual of empowerment into these systems creates a group centred on the Tantric master, in theory a simple wheel-hub structure in which the master is supreme (indeed is equal to the buddhas) and the disciples are all at an equal level in their relationship with the master. ${ }^{28}$

In practice, relationships within these groups are likely to have been more complex, yet the ideal model for the Tantric group is very simple. It is inclusive, without restrictions based on gender or ethnic identities, making it a flexible system for group formation, cutting across boundaries of class, clan and ethnicity. It does not require the establishment of monasteries or other property in order to function. The primary method of sustaining its group identity is the repeated practice of rituals among which the empowerment ceremony is the most important. The latter may be seen to imbue its recipients with the 'emotional energy' that some sociologists see as crucial to sustaining group formations. ${ }^{29}$ Nevertheless, Tantric groups can have a strong economic resilience, due to the expectation that the disciples will contribute funds to the master as an offering in return for the empowerment. Crucially, this group dynamic is also self-replicating, in that disciples may become masters in their own right, creating further, often overlapping, wheel-hub structures.

After the collapse of state-sponsored monastic Buddhism in Tibet, the group dynamics of Tantric Buddhism do seem to have been particularly successful. A satirical poem found in one of the Dunhuang manuscripts (P. tib. 840) complains of the spread of Tantric Buddhism among the ordinary folk of the villages:

It is worth noting that this modern discourse has roots in the work of Durkheim, Emil, The Elementary Forms of Religious Life, trans. by Carol Cosman (Oxford: Oxford University Press, 2008 [1912]).

28 On group structures and their modelling, see Martin, John Levi, Social Structures (Princeton: Princeton University Press, 2009).

Of course, Tantric disciples are theoretically at the same level as the master in that they identify with the deity in the process of empowerment and sādhana; however, in structural terms, the master is supreme. 
For every hundred students there are a thousand teachers, And nobody listens to the divine dharma.

For every village there are ten masters,

And the number of vajra assistants is uncountable. ${ }^{30}$

While this satire probably overstates the case, it is testament to the unease felt in some quarters at the successful self-replication of Tantric groups outside of institutional settings. Similar sentiments are expressed in the edict published by the West Tibetan King Yeshe Ö (Tib. Ye shes 'od, c. 959-1040), addressed to the 'masters of mantra who live in the villages'. The increasing power of these Tantric masters was a threat to those attempting to establish their authority on the old imperial model. Yeshe Ö's intention to re-establish the old hierarchies is clear when he compares the village masters to a beggar pretending to be a king. ${ }^{31}$ It is unlikely that the situation was quite as bad as the author of the satirical poem or Yeshe Ö suggests; a major barrier to teachers outnumbering students would have been economic, as the wheel-hub system is reliant on a group of disciples giving enough to support the master.

The economic aspect of these Tantric relationships is defended in an early tenth-century treatise by the Tibetan master Nyen Palyang (Tib. gNyan dPal dbyangs):

Question: 'When the Tantric master requests an offering at the time of empowerment, isn't this just something they've made up?'

Answer: 'The enlightened path to liberation is an eternal treasure That is found after having been lost on the road of samsāra for innumerable aeons. It wouldn't be excessive to offer one's life ten million times, not to mention anything else. The truth or falsity of this can be checked in any of the secret tantras. ${ }^{32}$

$30 \quad$ P. tib. 840: /slob ma brgya la slobs dpon stong//Lha chos nyan pa'i myi ma chis//grong tsan gcig la slobs dpon bcu//las kyi rdo rje gra[ng]s kyang myed/

31 On Yeshe Ö's edict see Karmay, Samten, The Arrow and the Spindle: Studies in History, Myths, Rituals and Beliefs in Tibet (Kathmandu: Mandala Book Point, 1998), 3-16. For an insightful discussion of the political and religious background to the edict, see Dalton, The Taming of the Demons, 95-109.

32 IOL Tib J 470: [...] /slobs la dbang mnod pa'i dus su//yon 'bul 'tshal lo/ zhes bgyi ba rang bzo ma lags sam//skal pa grangs myed 'das par lam skol gdod rnyed pa//bla med byang chub thar lam g.yung drung gter//des ni lus srog bye bas gcal kyang ma ches na//gzhan lta ci smos bden rdzun gsang ba'i rgyud la kun ltos/ [...] 
The economy of Tantric Buddhism in Tibet is also apparent in the traditional Tibetan histories, which often recount the difficulties that prospective students had in raising sufficient funds to receive instruction from a famous master. These histories also relate how certain famous figures from the 11th and 12th centuries, such as Marpa Chokyi Lodro (Tib. Mar pa chos kyi blo gros, 1012-1097) and Lama Zhang Yudragpa (Tib. bLa ma Zhang g.yu brag pa, 11221193), successfully formed large groups of students, became relatively prosperous, and applied their religious authority to their secular ambitions towards power and property. ${ }^{33}$ We can connect these accounts with figures like Juesiluo and his followers who were ruling the Tsongkha confederation in Northeast Amdo in the 11th century. The social situation across Tibetan and Central Asia was politically fragmented, allowing the formation of small groups like these around charismatic figures. Though the Chinese sources do not mention it, it is likely that the dynamics of Tantric Buddhism were also involved in the case of the Tibetan-speaking groups of Amdo and Central Asia.

The survival of the Tibetan language beyond the tenth century is probably also due in part to its role in Tantric groups. Tsuguhito Takeuchi has pointed out that Tibetan was not only used as a lingua franca between people of different ethno-linguistic backgrounds, but by people from the same background, such as two Chinese correspondents. He suggests that "Tibetan evidently acquired a sort of 'fashionable' image, or sociolinguistic prestige, which promoted further use." ${ }^{34}$ Takeuchi did not suggest a reason for this, but it may well be that the prestige of the Tibetan language was a direct consequence of the success of Tantric teachers and their propagation of Mahāyoga practices which were only available in the Tibetan language. From the 11th to 14th centuries Tibetan Tantric practices became even more influential in Central Asia as they were adopted by emerging powers, to which we now turn.

\section{6}

Among the Turks

The Uyghur Turkic Empire ruled the Northern steppes from the mid-8th to mid-9th century, until their enemies, the Kirghiz, conquered them. From then onwards large groups of Uyghur Turks fled South across the mountains. The largest group settled in towns along the Northern edge of the Taklamakan

33 For an insightful analysis of Lama Zhang's activities, see Yamamoto, C. S., "Vision and Violence: Lama Zhang and the Dialectics of Political Authority and Religious Charisma in Twelfth-Century Central Tibet” (PhD diss., University of Virginia, 2009). 
desert including Kučã and the Turfan region; others ended up further South in the region which is now Gansu, where they established a minor kingdom based in the town of Ganzhou (甘州, modern Zhangye 張掖). By the 1oth century there were Uyghurs in Dunhuang as well. Surrounded by Tibetan and Chinese Buddhists, many of these Uyghurs learned to write in Chinese and Tibetan and adopted Buddhism. Buddhist texts, especially Mahāyāna sūtras, were translated into Uyghur, mainly from Chinese. ${ }^{35}$

Before using their own language to write Buddhist texts, the Uyghurs used the Chinese and Tibetan languages. ${ }^{36}$ Manuscripts from the 1oth century in the Dunhuang collections provide a useful insight into the multilingual skills of the Uyghur Turks in Central Asia, and also their adoption of Buddhism and belief in the efficacy of religious merit generated by activities such as copying books. One illuminated manuscript (IOL Tib J 1410) has a copy of a Chinese sütra (the shorter Sukhāvatīyunha) in the Tibetan script. It appears that the scribe who wrote the manuscript knew spoken Chinese but not the written characters, so used the Tibetan alphabet instead. In a colophon, the scribe writes that he comes from the country of the Kirghiz (Tib. gir kis) though he now lives in Hexi, the region that contains Dunhuang. The colophon goes on to

35 On the Uyghurs at Dunhuang, see Moriyasu, Takao, "The Sha-chou Uygurs and the West Uygur Kingdom," Acta Asiatica 78 (2000); Russell-Smith, Lilla, Uygur Patronage at Dunhuang (Leiden: Brill, 2005). The first reference in a Chinese source to 'Uyghurs of Ganzhou and Shazhou' is in 980, and Moriyasu cites the first reference to the Shazhou (that is, Dunhuang) Uyghurs as the rulers of Dunhuang in a letter dated to 1014 (Moriyasu, "The Sha-chou Uygurs," 33), though the exact political role of the Uyghurs in Dunhuang is still uncertain. In the same article (Moriyasu, "The Sha-chou Uygurs," 39-40) he argues that the Uyghurs of Dunhuang (Shazhou) had stronger connections with those at Kočo (that is the Turfan region) than those at the nearer city of Ganzhou. After the 14th century the Uyghurs gradually converted to Islam. However, the Uyghurs of Hexi (that is of Dunhuang and Ganzhou) remained Buddhists, and today are considered a separate ethnic minority in China, known as the Sarig Yugurs.

36 An example of Uyghurs using the Tibetan script to write a Buddhist catechism has been studied by Moriyasu Takao 森安孝夫, “Chibetto moji de kakareta uiguru bun bukkyō kyōri mondō (P. tib. 1292) no kenkyū チベット文字で書かれたウィグル文佛教教理 問答 (P. tib. 1292) の研究 [Études sur un catéchisme bouddhique ouigour en écriture tibétaine (P. tib. 1292)]," Ōsaka daigaku bungakubu kiyō 大阪大學文學部紀要 [Bulletin of Osaka University Literary Department] 25 (1985): 1-85. On the manuscript evidence of Uyghurs using the Chinese language, see Galambos, Imre, "Non-Chinese Influences in Medieval Chinese Manuscript Culture," in Frontiers and Boundaries: Encounters on China's Margins, ed. Zsombor Rajkai and Ildikó Bellér-Hann (Wiesbaden: Harrassowitz, 2012), 83-84. For the development of Buddhism among the Uyghurs see also the chapter by Jens Wilkens in this volume. 
list a dozen or so Buddhist texts (mostly by their Chinese titles) that the scribe has copied and then recited in a single day as an offering to "the buddha, the gods and nāgas of the eight quarters, and the protectors of the four directions." By the merit of this, he hopes that one day he will be able to return to his own country, and that after he dies, he will be born free of suffering, not in hell, and preferably in the god realms. ${ }^{37}$

Further evidence of the merging of Turkic and Tibetan languages in the Buddhist practices of the Uyghurs is found in the manuscript P. tib. 1292, a Uyghur Buddhist catechism written using the Tibetan script. The handwriting of this manuscript is an accomplished style seen in many other 1oth century Tibetan manuscripts from Dunhuang, suggesting that the use of Uyghur alongside Tibetan was well established in the local Buddhist community by at least the end of the 1oth century. These manuscripts stand at the beginning of a long period of Tibeto-Uyghur interaction, in which Tantric Buddhism played a major role. There are also Buddhist manuscripts in the Uyghur language and script from the library cave at Dunhuang dating from much later: the 13th and 14th centuries. These were not among the original cache sealed up in the early 11th century, but seem to have been taken from other caves and placed in the library cave by Wang Yuanlu (王圓籙, c. 1849-1931), the monk who sold the manuscripts to two explorers and scholars Stein and Pelliot in between the monk's discovery of the cave in 1900 and Stein's visit in 1907.

These later Uyghur manuscripts relate to the period of Mongol power in Central Asia. They overlap with the much more numerous Uyghur manuscripts from the Turfan region, which are now held in Berlin and generally date from the 11th to 14th centuries, so we should consider them alongside these. The Uyghur Kingdom based in Turfan was closely allied with the Uyghurs of

37 On this manuscript, see also Thomas, F. W., and G. L. M. Clauson, "A Second Chinese Buddhist Text in Tibetan Characters," Journal of the Royal Asiatic Society 2 (1927): 281-306.

The complete colophon is as follows: / stag gi lo'i dbyar/ /gir kis yul du ha se to ab 'ga den chung shi 'gi/ /khang re man gyis/ the'u kyig shi chor lha 'tso'i yid dam du bsngos te// [a] myi 'da kyi bam po gcig dang/par yang kyi bam po gcig [dang/] kwan im kyi bam po gcig dang/ta sim kyi bam po gcig [dang/] phyogs bcu'i mtha yas bam po gcig dang//bkra shis bam po gcig dang//de 'bur te ci'u bam po bcig dang//'da la 'ji ci'u bam po gcig dang/ bzang po spyod pa smon lam dang//'thor bshags la stsogs te/ /gong nas smon pa 'di rnams/ lyi dam du bris pa 'di/ /gdugs gcig klag ching//sangs rgyas dang/ Lha klu sde brgyad dang/ phyogs bzhi'imgon po la mchod cing/yi dam du bcas te//lha 'tsho tshe lus la bsam pa thams cad grub ching yul du sngar phyin pa dang/ tshe slad ma la gar skyes kyang//sdug bsngal dang bral ching/ /na rag du myi rtung bar byin gyis skabs te/ lha yul du skye bar shog shig// 
Dunhuang, so contemporaneous manuscripts from these two sites derive from the same political and religious milieu.

The majority of the Tibetan manuscripts and block prints from Turfan date from after the fall of the Tibetan Empire. They show that the Tibetan language continued to be used, especially for Buddhist literature, alongside Uyghur and Chinese in Turfan. ${ }^{38}$ And just as Tibetan had been the language of the most advanced forms of Tantric Buddhism at Dunhuang during the 1oth century, by the 13th and 14th centuries it was the language of the new literature and techniques of the later phase of translation (Tib. phyi dar) in Tibet. During the period of Mongol rule (13th and 14th centuries), several of these Tantric texts were translated into Uyghur. Among the Turfan manuscripts are a guruyoga composed by Sakya Paṇdita (Tib. Sa skya paṇitita, 1182-1251), a sādhana of Avalokiteśvara featuring a dark-skinned Padmasambhava, and a commentary on the Six Yogas of Nāropa (Tib. nā ro chos drug). The later Uyghur manuscripts from Dunhuang include a major sādhana for a Cakrasamvaāra maṇdala, which mentions the name of the third Karmapa Rangjung Dorje (Tib. Kar ma pa Rang byung rdo rje, 1284-1339).

The manuscript evidence for Tantric practices is complemented by some of the artistic representations in the painted caves of the Turfan region, which show Tibetan stylistic features and Tantric content. ${ }^{39}$ However, since these depictions have rarely been studied by Tibetologists, this has not always been recognised. An interesting example is the clay head M III 8541, which bears the iconography of Mahākāla_-dark blue skin, red bushy eyebrows, fangs and red fire streaming from the mouth-but has not been recognised as such and has been dated to 8th-9th centuries. If this is in fact a representation of Mahākāla, a more likely date range would be 12 th-14th centuries. ${ }^{40}$

Although these new Tantric texts came from lineages based in Central Tibet, this was only possible because Central Asian Uyghurs were already able to use the Tibetan language and script. Study of loan words in these Uyghur translations of Tibetan Tantric texts has shown that they reflect the pronunciation of Eastern Tibet, particularly Amdo. Thus while the texts may have been transmitted long-distance, the main interface between the Uyghur and Tibetan languages and peoples was local to Eastern Central Asia. As we move

38 The catalogue of the Tibetan manuscripts in the Berlin Turfan collection is Taube, Manfred, Die Tibetica der Berliner Turfansammlung (Berlin: Akademie Verlag, 1980).

39 Personal communication with Kira Samosiuk, St Petersburg, September 2013.

40 See Härtel, Herbert, and Marianne Yaldiz, Along the Ancient Silk Routes: Central Asian Art from the West Berlin State Museums (New York: Abrams, 1982), 151-153, where the head is described only as a 'demon' and dated to the 8th-9th centuries. 
into the period of Mongol domination over Central Asia, there are clear continuities in the use of Uyghur and Tibetan languages and scripts side by side by Buddhists, and the popularity of the most recent developments of Tibetan Tantric Buddhism. ${ }^{41}$

The Tanguts ruled over a significant Central Asian kingdom from the late 1oth to the early 13th century, when they were conquered and absorbed into the Mongol Empire. They expanded from their base in the Ordos desert in Inner Mongolia through conquest of the two main Uyghur Kingdoms of the Northern Taklamakan desert, and the minor Tibetan Kingdoms to the East of Lake Kokonor, parts of the former Tsongkha confederation. They also captured territory further East from the expanding Chinese Song Dynasty. The Tangut ruler Yuanhao (r. 1032-1048, 元昊) of the Ngwemi Dynasty declared himself emperor of the Tanguts, Uyghurs, Tibetans and Tartars, and initiated state-building cultural projects including the standardisation of a Tangut writing system. ${ }^{42}$

The Tanguts spoke a Tibeto-Burman language and practiced a religion with similarities to the pre-Buddhist religion of Tibet. They must also have been aware of Buddhism through contact with Chinese and Tibetan Buddhist texts and practices, and in 1038 Yuanhao followed the example of the Tibetan King Tri Song Detsen and the early emperors of the Chinese Song Dynasty in establishing a major project to translate the Buddhist scriptures into the Tangut language. The first part of this process involved mainly Chinese originals from the tripitaka; by the end of the 11th century 3,579 scrolls are reported to have been

41 On the Uyghur Tantric literature translated from Tibetan in the Berlin collection, see the transliterations and translations in Kara, Georg, and Peter Zieme, Fragmente tantrischer Werke in Uygurischer Übersetzung (Berlin: Akademie Verlag, 1976). The Nāropa text is in the Stein manuscript Or. 8212/109, and is transliterated and translated in Zieme, Peter, and Georg Kara Ein Uigurisches Totenbuch (Wiesbaden: Otto Harrossowitz, 1978).

In Chinese sources the Tangut Empire is referred to as Xixia (西夏). These words are not found in Tangut sources, however, which refer to the empire as 'The Great State of White and High' and its people as Mi-nia. See Kepping, Ksenia, "Mi-Nia (Tangut) Selfappellation and Self-portraiture in Khara-Khoto Materials" in Последние статьи и документь [Last Works and Documents] (St Petersburg: Omega Publishers, 2003), 97-98. In Tibetan they are referred to as Mi nyag. 
translated. Then from the middle of the 12th century the translation project shifted its focus more towards Tibetan texts. ${ }^{43}$

The Tangut manuscripts and block prints discovered in the ruins of Kharakoto, most of which are now in St Petersburg and London, give a sense of the kind of Tibetan texts that were chosen for translation into Tangut. ${ }^{44}$ The increasing influence of Tibetan Buddhists at the Tangut court in the 12th century, and of certain Kagyu lineages in particular, is shown by the number of texts associated with these lineages translated into Tangut in the latter period of the empire. These include Mahāmudrā instructions and ritual texts of Cakrasaṃvara, Vajrayoginī and Vajravarahī. Lamdre (Tib. lam 'bras) and Dzogchen (Tib. rdzogs chen) texts are also found in the Tangut texts from Kharakoto. The non-tantric texts are mostly from Kadam lineages, with the works of Atiśa predominating. ${ }^{45}$

This range of texts in the Tangut language and script is complemented by manuscripts written in Chinese and Tibetan that were also recovered from Kharakhoto and new discoveries in the Ningxia region. The Chinese texts from the Tangut Kingdom include translations from Tibetan Tantric literature, including the Cakrasamvvara and Sampuța tantras, Lamdre texts, a series of works related to the Six Yogas of Nāropa ${ }^{46}$ Tantric literature also predominates

43 Kychanov, E. I., "The State of Great Xia (982-1227 AD)," in Lost Empire of the Silk Road: Buddhist Art from Khara Khoto (10-13th century), ed. Mikhail Piotrovsky (Milan: ThyssenBornemisza Foundation/Electa, 1993), 55-57. Elsewhere Kychanov, E. I., "From the History of the Tangut Translation of the Buddhist Canon," in Tibetan and Buddhist Studies Commemorating the 2ooth Anniversary of the Birth of Alexander Csoma de Körös, ed. Louis Ligeti (Budapest: Akadémiai Kiadó 1, 1984), 381-382 states that the earliest Tangut translation from Tibetan was Amitābhavyūha, completed in 1094. See also Dunnell, Ruth, "Esoteric Buddhism under the Xixia (1038-1227)," in Esoteric Buddhism and the Tantras in East Asia, ed. Charles D. Orzech, Henrik H. Sørensen and Richard K. Payne (Leiden: Brill, 2011), 465-477, for an account of Tibetan Tantric Buddhism at the Tangut court.

44 For an excellent account of the discovery and study of the Tangut manuscripts, see Galambos, Imre, Chinese Literature in Tangut: Manuscripts and Printed Books from Kharakhoto, Berlin: De Gruyter, 2015 .

45 The first serious overview of the Tibetan-related texts in the Tangut collections is Solonin, Kirill. "Dīpaṃkara in Tangut Context: An Inquiry into Systematic Nature of Tibetan Buddhism in Xixia (Part 1), forthcoming.

46 For examples of Chinese Tantric manuscripts from Kharakhoto see Shen Weirong,

"Reconstructing the History of Buddhism in Central Eurasia (11th-14th Centuries): An Interdisciplinary and Multilingual Approach to the Khara Khoto Texts," in Edition, éditions: L'Écrit au Tibet, évolution et devenir, ed. Anne Chayet, Christina ScherrerSchaub, Françoise Robin and Jean-Luc Achard (Munich: Indus Verlag, 2010) 1-26. On the Tibetan manuscripts from Kharakhoto in the British Library, see Iuchi M., "Bka' 
in the Tibetan manuscripts from Kharakhoto, showing that the Tibetan language continued to be used in the practice of Tantric Buddhism at the same time as the texts were being translated into Tangut and Chinese. The fine paintings of Tantric deities recovered from Kharakoto (now at the Hermitage in St Petersburg) offer further evidence of the Centrality of Tibetan Tantric Buddhist networks to Tangut culture. ${ }^{47}$

Tibetan religious histories provide interesting evidence of other Tantric lineage networks that were influential in the Tangut Kingdom. The most significant Tangut figure in these histories is Tsami Lotsawa Sangye Dragpa (Tib. rTsa mi Lo tsa ba Sangs rgyas grags pa, fl. 12th c.), who travelled from the Tangut Kingdom to India and Tibet, where he was active as a translator. His translation work includes texts from the Kālacakra tradition, and a series of texts centering on the wrathful protector Mahākāla. These include one entitled The Usurpation of Government (Tib. rGyal srid 'phog pa), which, as Elliot Sperling has pointed out, is "a short but direct 'how-to' work on overthrowing the state and taking power." 48 As Sperling argues, this strongly suggests that the cult of Mahākāla at the court of Qubilai Qan and his successors was directly inherited from the Tangut court.

Among Tsami Lotsawa's students was another translator, an Amdo Tibetan known as Ga Lotsawa or Galo for short (Tib. rGwa Lo tsa ba, fl. 12th century), who also specialised in Kālacakra and Mahākala. Several of Ga Lotsawa's own compositions appear in a long Tibetan scroll in the St Petersburg collections, Dx-178, connecting him to the Tangut state as well. This scroll has been studied by Alexander Zorin, who has shown that it is a collection of mainly wrathful ritual texts, comprising thirteen texts on various forms of Mahākāla, eight texts on Narasinha (a form of Viṣnu), and a sādhana for the maṇdala of Vajrapāni and the eight nāga kings. The texts authored by Ga Lotsawa include one aimed

gdams pa Manuscripts Discovered at Khara-Khoto in the Stein Collection," in B. Dotson, C. A. Scherrer-Schaub and T. Takeuchi (eds.), Old and Classical Tibetan Studies, Proceedings of the nth Seminar of the International Association for Tibetan Studies, Königswinter, 2006. Halle, forthcoming.

47 Examples can see seen in Piotrovsky, Mikhail ed., Lost Empire of the Silk Road: Buddhist Art from Khara Khoto (10-13th century) (Milan: Thyssen-Bornemisza Foundation/Electa, 1993), 106-249, as well as on the website of the Hermitage Museum (www.hermitage museum.org, accessed 4 February 2015).

48 Sperling, Eliot, "Rtsa-mi Lo-tsa-bā Sangs-rgyas Grags-pa and the Tangut Background to Early Mongol-Tibetan Relations," in Tibetan Studies: Proceedings of the 6th Seminar of the International Association for Tibetan Studies, ed. Per Kvaerne (Oslo: Institute for Comparative Research in Human Culture, 1994), 805. 
at the oppression of enemies, implying the same kind of martial use as the Mahākāla text translated by Tsami Lotsawa just mentioned. ${ }^{49}$

The Tibetan historical sources linking Tsami and his student Galo to the Tangut Empire have not so far been corroborated with sources in Tangut; however, the study of Tangut texts related to Tibetan lineages is still in its infancy, and it is possible that both are in fact found in Tangut colophons. For example, the colophon of Tang. 167 appears to contain Tangut characters transliterating the Tibetan rtsa mi as the source of the teaching, while the colophon of Tang. 308 states that the text was received from a lhie je kia lio (Tib. Lha rje rGwa lo?). ${ }^{50}$ Furthermore, the appearance of Lama Zhang Yudragpa in the Tangut colophons suggests that this particular Tantric lineage was Central to the transmission of Tantric Buddhism to the Tangut Kingdom, as Lama Zhang was also a student of Ga Lotsawa. ${ }^{51}$

The Kharakhoto manuscripts can also help us to identify figures of more local significance involved in these same lineages. A Tibetan teacher mentioned in several colophons as transmitting or compiling Tantric texts, Yarlungpa Chokyi Senge (Tib. Yar lungs pa Chos kyi seng ge) is associated with texts by Lama Zhang (Tang. 182 and 489). He is also listed as responsible for transmitting the text possibly attributed to Ga Lotsawa in Tang. 308. Though he was clearly an important figure in Tangut Buddhist networks-at least those represented by the Kharakhoto manuscripts - this Yarlungpa has not been linked to the Tibetan historical record. ${ }^{52}$

Towards the end of the Tangut Empire, the increasing influence of Tibetan lamas at the Tangut court was formalised with the appointment the Tibetan monk Tsangpopa (Tib. gTsang po pa, 1189-1258) as imperial preceptor (Chin. dishi 帝師) at the Tangut capital Xingzhou (興州). Tsangpopa served the emperor till his death in Liangzhou in 1218/19. His successor was Tishi Repa (Tib. Ti

49 See Zorin, Alexander, "A Collection of Tantric Ritual Texts from an Ancient Tibetan Scroll Kept at the Institute of Oriental Manuscripts of the Russian Academy of Sciences," Journal of the International College for Postgraduate Buddhist Studies 17 (2013).

$5^{0}$ As there is at the time of writing no Unicode Tangut encoding, the phonetic reconstructions of Kychanov are used here.

$5^{1} \quad$ Here I have relied on the transcriptions of Tangut titles and colophons of Buddhist texts in Nishida Tatsuo, The Hsi-Hsia Avataṁsaka Sūtra, vol. 3 (Kyoto: Kyoto University Faculty of Letters, 1977), 13-59.

$5^{2}$ The Yarlungpa mentioned in the colophons is probably not to be identified with other translators of that name discussed in Leonard van der Kuijp, "On the Vicissitudes of Subhūticandra's Kāmadhenu Commentary on the Amarakoșa in Tibet," Journal of the International Association of Tibetan Studies 5 (2009): 29-36. 
shi ras pa, 1164/5-1236), who had studied in Tibet with several famous lamas including the above-mentioned Lama Zhang, whom he assisted in battle with the Tantric rituals of Mahākāla. Expertise in these rituals helped his rise to the position of imperial preceptor and Tibetan historical sources tell of his use of Mahākāla rites to defeat, if only temporarily, the Mongol armies of Činggiz Qan. ${ }^{53}$

The Tibetan historical accounts of Tishi Repa can be linked to some of the figures and lineages found in the colophons of the Kharakhoto manuscripts. ${ }^{54}$ His association with Lama Zhang accords with the appearance of Zhang's name and the Tantric practices associated with him in the colophons. The local figure Yarlungpa Chokyi Senge also makes an appearance in these Tibetan texts. According to the Dharma History of Lhorong (Tib. Lho rong chos 'byung), Tishi Repa met a Yarlungpa in the Amdo area, while travelling through Tsongkha and Lingzhou. ${ }^{55}$ That Tishi Repa met Yarlungpa in Amdo also suggests that this area was a significant hub in the transmission of Tibetan Tantric lineages to the Tangut Kingdom.

Indeed, many of the Amdo sites mentioned in the Dharma History of Lhorong correspond to locations in the 1oth-century Tibetan letters of passage discussed above, and indicate the persistence of a network of Tibetan Buddhist monasteries and teachers in this area, as hubs in wider networks extending to Central Asia, Tibet and China. The Dharma History of Lhorong tells us that Tishi Repa first heard of the Tangut king through a travelling Amdo mercenary, an anecdote that allows us to imagine how micro-encounters associated with

53 On Tsami Lotsawa and Sangye Repa, see Sperling, Elliot, "Lama to the King of Hsia," The Tibet Journal 7 (1987); Sperling, "Rtsa-mi Lo-tsa-bā Sangs-rgyas Grags-pa"; Sperling, Elliot, "Further Remarks Apropos of the 'Ba' rom pa and the Tanguts," Acta Orientalia Academiae Scientiarum Hungaricae 57.1 (2004).

54 For summary and discussion of recent work on the names of Tangut, Chinese and Tibetan translators and authors in the colophons of the Kharakhoto manuscripts, see Dunnell, Ruth, "Translating History from Tangut Buddhist Texts," Asia Major, Third Series 22.1 (2009). See also Dunnell, Ruth, "Esoteric Buddhism Under the Xixia (1038-1227)."

55 See Rta tshag tshe dbang rgyal, Lho-rong Chos-byung (Lhasa: bod ljongs bod yig dpe rnying dpe skrun khang, 1994), 214. The Dharma History of Lhorong was compiled in the 15th century, but contains older sources. A modern history of the Barompa Kagyu school by Mati Ratna gives the full name Yarlungpa Senge Gyaltsen (Tib. Yar lung pa seng ge rgyal mtshan); see Sperling, "Further Remarks Apropos of the 'Ba' rom pa and the Tanguts," 8,13 . However, as Sperling points out, this is a late text drawing upon other, unspecified, sources. 
these networks encouraged the historically significant cross-cultural relationships established in the Tangut and Mongol courts. ${ }^{56}$

After the conquest of the Tangut capital Xingzhou (興州) in 1226/7, in which Činggiz Qan also lost his life, Tishi Repa is said to have returned to Tibet. ${ }^{57}$ Other Tibetan lamas soon appeared at the courts of Činggiz Qan's successors, and less than twenty years later, the Mongol ruler of Eastern Central Asia and Tibet, Goden Qan, invited Sakya Pandita to his court to negotiate the submission of Tibet to Mongol rule. In the following generation, Sakya Pandita's nephew Pakpa (Tib. Phags pa, 1235-1280) was given the title of imperial preceptor by Qubilai Qan in 1269, on the model established in the Tangut court. The continuities also extend to the Central role of Tantric Buddhism in this relationship, as Pakpa had already established a patron-priest relationship with Qubilai in 1258 by conferring empowerment upon him, just as Tishi Repa had done for the Tangut emperor. ${ }^{58}$

With the Mongol Empire, the patron-priest relationship and the Centrality of the Tantric dynamic of master and student came to centre stage in the geopolitics of Tibet, Eastern Central Asia and China. This paradigm determined the dynamics of the relationships between Tibet and subsequent Chinese, Mongol and Manchu powers. A version of it was still being invoked by Tibetan monastics during the crucial period of negotiation with the Chinese Communist Party in the 1940 and 50 s. $^{59}$

\section{Conclusion}

The evidence that I have assembled here is scattered across different languages and various forms of text; yet it allows us to perceive a pattern, suggesting the wider significance of the multi-linguistic and multi-ethnic milieu of Eastern Central Asia in the larger political networks that developed across Asia. Archaeological evidence from manuscripts found in Central Asian sites

\footnotetext{
56 Sperling, "Further Remarks Apropos of the 'Ba' rom pa and the Tanguts," 15, 16.

57 On the Chinese and Tangut sources for this event, see Kepping, "Chinggis Khan's Last Campaign," $172-77$.

$5^{8}$ On the role of Tantric Buddhism at the Mongol/Yuan court, see Shen Weirong, "Tibetan Buddhism in Mongol-Yuan China (1206-1368)," in Esoteric Buddhism and the Tantras in East Asia, ed. Charles D. Orzech, Henrik H. Sørensen and Richard K. Payne (Leiden: Brill, 2011).

59 See van Schaik, Sam, Tibet: A History (London: Yale University Press, 2011), 196-203, 216. For a more detailed account, see Goldstein, Melvyn, A History of Modern Tibet, Volume 1: 1913-1951, The Demise of the Lamaist State (Berkeley: University of California Press, 1989), $798-813$.
} 
such as Dunhuang and Kharakoto has allowed us to explore the agency of local Buddhist teachers and patrons from this region, figures who were ignored by the compilers of historical literature in more Central regions. It may not be possible to fully trace the causes and conditions that explain why Tibetan Buddhism was so successful in Eastern Central Asia. However I will offer a tentative suggestion.

Up to the 9th century, Buddhism was primarily practised via Sanskrit as a 'church language' across Central Asia up to the Hexi corridor, and via the Chinese language East of there. ${ }^{60}$ From the 9 th century, the transitional period that Christopher Beckwith has called 'the collapse of the early medieval world order', the influx of new peoples into Central Asia-Tibetans, Uyghurs, Tanguts and then Mongols_-brought major change. ${ }^{61}$ Buddhism was adapted by the Uyghurs and Tanguts, while the old sites of Indic Buddhism-Khotan, Kučã and so on-declined in influence or began to convert to Islam. Tibetan Buddhism, with its Tantric group dynamics cutting across linguistic and cultural boundaries, performed the same function that Sanskritic Buddhism had previously. With the growth of translation and composition in vernacular languages such as Khotanese and Kuchean, there was no longer a single church language facilitating cross-cultural religious dynamics, and it was this role that was taken by Tibetan.

In any case, I hope to have shown here that manuscripts, and other artefacts made and used by the same communities, are crucial sources for our understanding of the geopolitical role of Tibetan Tantric Buddhism. The examples above show the practice of Tantric Buddhism - generally derived from Tibetan sources-across a variety of ethnic and linguistic groups. I have suggested that we can look for one reason for this by focusing on group dynamics, examining the effectiveness of Tantric Buddhist practices in facilitating the formation of social groups across ethnic and linguistic boundaries. The significant relationships described in traditional histories, such as that between Chogyal Pakpa and Khubilai Qan, were only possible due to the conditions established by a multitude of local events unrecorded by historians but accessible to us through manuscripts and other artefacts. To put it in more theoretical terms, these are the micro-histories that make the conditions for macro-history.

6o On the use of Sanskrit in Central Asia see for example Sander, Lore, "Early Prakrit and Sanskrit Manuscripts from Xinjiang," in Buddhism across Boundaries: Chinese Buddhism and the Western Regions (Taipei: Fo Guang Shan Foundation for Buddhist \& Culture Education, 1993), and on Sanskrit as a 'church language' see Nattier, Jan, "Church Language and Vernacular Language in Central Asian Buddhism," Numen 37.2 (1990). 